\title{
Identification of risk factors associated with highly pathogenic avian influenza H5N1 virus infection in poultry farms, in Nigeria during the epidemic of 2006-2007
}

\author{
Folorunso O. Fasina a,b,e,*, Ariel L. Rivas ${ }^{\mathrm{c}}$, Shahn P.R. Bisschop ${ }^{\mathrm{d}}$, Arjan J. Stegeman ${ }^{\mathrm{e}}$, \\ Jorge A. Hernandez ${ }^{f}$ \\ a National Veterinary Research Institute, Vom, Nigeria \\ b Department of Farm Animal Health, Faculty of Veterinary Medicine, Utrecht University, Yalenaan, The Netherlands \\ c Department of Population Health and Pathobiology, College of Veterinary Medicine, North Carolina State University, NC, USA \\ d Poultry Reference Centre, Department of Production Animal Studies, Faculty of Veterinary Science, University of Pretoria, South Africa \\ e Department of Infectious Diseases and Immunology, Faculty of Veterinary Medicine, Utrecht University, Yalenaan, The Netherlands \\ ${ }^{\mathrm{f}}$ Department of Large Animal Clinical Sciences, College of Veterinary Medicine, University of Florida, Gainesville, FL, USA
}

\section{A R T I C L E I N F O}

\section{Article history:}

Received 21 February 2010

Received in revised form 3 November 2010

Accepted 4 November 2010

\section{Keywords:}

Avian influenza

H5N1

Risk factors

Nigeria

Poultry

\begin{abstract}
A B S T R A C T
We conducted a matched case-control study to evaluate risk factors for infection with highly pathogenic avian influenza (HPAI) H5N1 virus in poultry farms during the epidemic of 2006-2007 in Nigeria. Epidemiologic data were collected through the use of a questionnaire from 32 case farms and 83 control farms. The frequency of investigated exposure factors was compared between case and control farms by using conditional logistic regression analysis. In the multivariable analysis, the variables for (i) receiving visitors on farm premises (odds ratio $[\mathrm{OR}]=8.32 ; 95 \%$ confidence interval $[\mathrm{CI}]=1.87,36.97 ; P<0.01$ ), (ii) purchased live poultry/products $(\mathrm{OR}=11.91 ; 95 \% \mathrm{CI}=3.11-45.59 ; P<0.01)$, and (iii) farm workers live outside the premises $(\mathrm{OR}=8.98 ; 95 \% \mathrm{CI}=1.97,40.77 ; P<0.01$ ) were identified as risk factors for HPAI in poultry farms. Improving farm hygiene and biosecurity should help reduce the risk for influenza (H5N1) infection in poultry farms in Nigeria.
\end{abstract}

(c) 2010 Elsevier B.V. All rights reserved.

\section{Introduction}

In 1996, a geese farm was infected in Guangdong, China with the highly pathogenic H5N1 strain of avian influenza (HPAI H5N1). That particular incident was to mark the onset of a major catastrophe in the poultry industry world wide as the virus from the farm acquired several new biological properties and became the progenitor of several other HPAI H5N1 viruses-the key among which is the Zgenotype (Xu et al., 1999; Guan et al., 2002; Li et al., 2004). The virus has caused the death or culling of over 300 million

\footnotetext{
* Corresponding author at: National Veterinary Research Institute, Vom, Nigeria. Tel.: +234703 3128949 .

E-mail address: daydupe2003@yahoo.co.uk (F.O. Fasina).
}

multiple avian species and spread to at least 50 countries, including 467 human infections and 282 human fatalities (OIE, 2010; WHO, 2010).

Several factors have been determined to be responsible for the dissemination of influenza virus in poultry. Bavinck et al. (2009) showed that raising of multiple species in backyard poultry and living in close proximity to infected commercial farm premises increases the risk of infection. Backyard poultry have also been found to be an important source of spread and persistence of HPAI H5N1 in South East Asia (Tiensin et al., 2005). Thompson et al. (2008) also found out that large population of birds within farm premises, poor biosecurity and presence of outside birds, especially the Egyptian geese, were associated with increasing the risk of infection of ostriches with the $\mathrm{H} 5$ influenza virus. Layer type operation has been associated 
with infection in the Netherlands (Thomas et al., 2005). Finally, a study by Nishiguchi et al. (2007) proved that introduction of end-of-lay chickens, sharing of farm equipment, poor biosecurity and proximity to infected farms are important risk factors for infection with HPAI H5N2 in Japan.

Nigeria was the first African country to report HPAI infection in February 2006, when the HPAI H5N1 virus was first detected in a commercial poultry farm in Kaduna, Northern Nigeria. The virus thereafter spread rapidly to other commercial and backyard poultry and infected 25 of 36 states of Nigeria including the Federal Capital Territory (National Veterinary Research Institute records). Approximately 711,000 birds of various species died and a total of $1,264,191$ were culled. One human fatality was also reported and confirmed in Lagos, South-West Nigeria in early 2007.

In Africa, despite reports on the genetic/biological constituents/properties of HPAI H5N1 viruses of African origin (Ducatez et al., 2006, 2007; Njouom et al., 2008; Couacy-Hymann et al., 2008; Cattoli et al., 2009; Fasina et al., 2009), the epidemiologic aspects of HPAI H5N1 virus infection in poultry have not been investigated. Although previous studies have provided an epidemiologic framework for investigation of risk factors for HPAI H5N1 virus in poultry (Henzler et al., 2003; Thomas et al., 2005; Bouma et al., 2009; Busani et al., 2009), study findings and proposed prevention strategies may not apply to the conditions of Nigeria in view of variations in climatic conditions, poultry practices, and the socioeconomic and cultural orientations of agricultural populations in this geographic region. The aims of this study were to investigate and identify risk factors for HPAI H5N1 virus infection in poultry farms in Nigeria during 2006-2007.

\section{Materials and methods}

\subsection{Study location and time period}

Field and laboratory investigations were conducted in Nigeria from February 2006 to October 2007. During this time-period, a total of 1205 poultry farms with suspected disease outbreaks were investigated, and 299 virus isolates of HPAI H5N1 were recovered from 26 of 36 states in Nigeria (Fasina et al., 2009). This epidemiologic investigation was conducted within a subset of the 26 states where one or more poultry farms reported HPAI H5N1 virus infections in 2006-2007. Seven states were randomly selected so that at least two states from each of the affected regions would be investigated. The final selection included: 2 states from the North (Kano, Kaduna); 3 states from the Central region (Bauchi, Plateau, Federal Capital Territory); and 2 states from the South (Ogun, Lagos; see Fig. 1). This design was meant not to assess the farms representative of all Nigerian poultry farms, but high-risk farms (those located within infected states). Within the selected states, case and control farms were selected as indicated below.
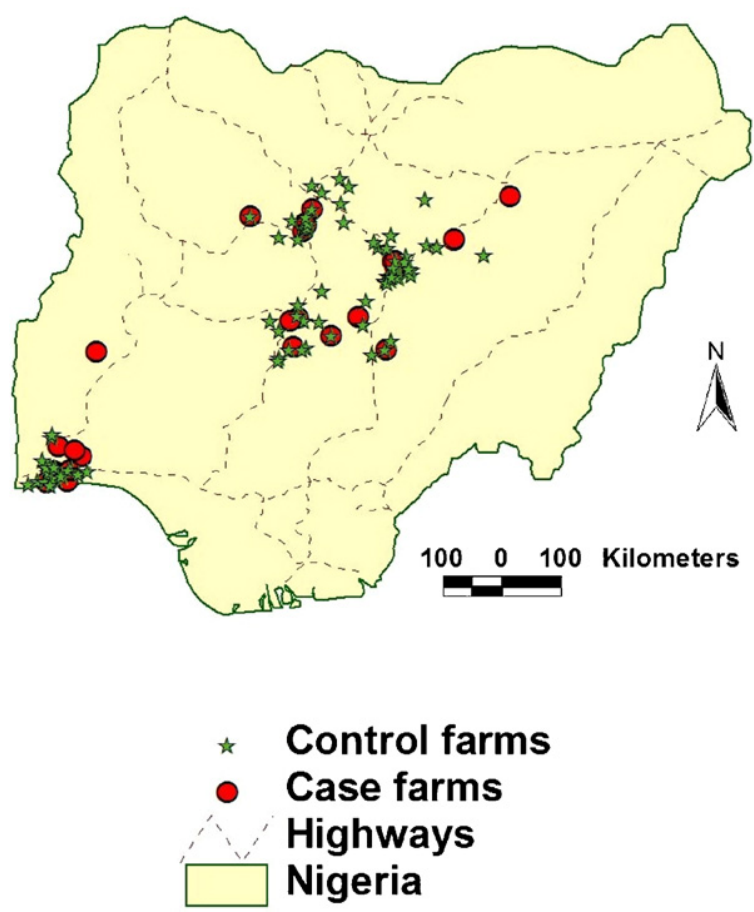

Fig. 1. Spatial representation of case and control farms in a case-control study on poultry farms in Nigeria. Sampled populations were taken from the infected areas using stratified random sampling approach.

\subsection{Selection of cases}

Case farms were randomly selected from the list of infected farms so that five farms from each of the selected states would be sampled $(n=35)$. Of those, questionnaires were completed and retrieved from thirty-two farms $(n=32)$. All the 32 farms met the double criteria of a case farm clinical signs - sudden heightened mortality, dyspnoea, coughing, wheezing, decreased food and water intake, decreased or cessation in egg production; and positive virological tests conducted at the National Veterinary Research Institute, Vom (Joannis et al., 2008).

\subsection{Selection of controls}

Control farms were randomly selected from a group of farms located in the same states that reported infection in 2006-2007 (sample frame: 2111). Serum samples had been collected and tested at the same time the epidemic occurred (to monitor other diseases), which produced seronegative test results for HPAI H5N1 virus. Control farms were selected to generate a ratio of 2.59:1 ( $83 \mathrm{farms}$ ).

The control farms were matched individually to case flocks using flock size $(<500$ or $>500 ; P$-value for measure of association between cases and controls $=0.015$, two-tailed at $95 \%$ confidence interval, McNemar test value $=5.898$ ).

\subsection{Epidemiologic questionnaire}

A structured questionnaire was designed, validated, and applied during farm visits for data collection of epi- 
Table 1

Univariable analysis of risk factors associated with poultry farms diagnosed with HPAI H5N1 virus infection in a case-control study on poultry farms in Nigeria.

\begin{tabular}{|c|c|c|c|c|c|c|}
\hline Variable & Category & Cases & Controls & OR & $95 \% \mathrm{CI}$ & $P$ \\
\hline \multirow[t]{2}{*}{ Location (urban) } & No & 19 & 46 & 1.00 & Reference & NA \\
\hline & Yes & 12 & 32 & 0.95 & $0.39,2.27$ & 0.91 \\
\hline \multirow[t]{2}{*}{ Primary occupation (poultry) } & No & 11 & 31 & 1.00 & Reference & NA \\
\hline & Yes & 20 & 47 & 1.16 & $0.47,2.84$ & 0.73 \\
\hline \multirow[t]{2}{*}{ Education (secondary maximum) } & No & 19 & 51 & 1.00 & Reference & NA \\
\hline & Yes & 12 & 27 & 1.25 & $0.51,3.05$ & 0.61 \\
\hline \multirow[t]{2}{*}{ Egg/spent layers disposed on farm } & No & 3 & 11 & 1.00 & Reference & NA \\
\hline & Yes & 28 & 67 & 1.57 & $0.39,6.22$ & 0.51 \\
\hline \multirow[t]{2}{*}{ Kept other birds/animals } & No & 23 & 73 & 1.00 & Reference & NA \\
\hline & Yes & 8 & 5 & 5.91 & $1.53,22.85$ & 0.01 \\
\hline \multirow[t]{2}{*}{ Visit other farms } & No & 14 & 24 & 1.00 & Reference & NA \\
\hline & Yes & 17 & 54 & 0.60 & $0.27,1.35$ & 0.22 \\
\hline \multirow[t]{2}{*}{ Receive visitors on premises } & No & 8 & 47 & 1.00 & Reference & NA \\
\hline & Yes & 23 & 31 & 3.69 & $1.50,9.08$ & $<0.01$ \\
\hline \multirow{2}{*}{ Purchase live poultry } & No & 11 & 64 & 1.00 & Reference & NA \\
\hline & Yes & 20 & 14 & 6.50 & $2.55,16.53$ & $<0.01$ \\
\hline \multirow[t]{2}{*}{ Have infected neighborhood } & No & 10 & 49 & 1.00 & Reference & NA \\
\hline & Yes & 21 & 29 & 3.48 & $1.40,8.69$ & $<0.01$ \\
\hline \multirow[t]{2}{*}{ Foot bath } & No & 12 & 24 & 1.00 & Reference & NA \\
\hline & Yes & 19 & 54 & 0.65 & $0.25,1.64$ & 0.36 \\
\hline \multirow[t]{2}{*}{ Gate/fence } & No & 15 & 34 & 1.00 & Reference & NA \\
\hline & Yes & 16 & 44 & 0.74 & $0.31,1.73$ & 0.49 \\
\hline \multirow[t]{2}{*}{ Changing room } & No & 23 & 53 & 1.00 & Reference & NA \\
\hline & Yes & 8 & 25 & 0.66 & $0.23,1.89$ & 0.44 \\
\hline \multirow[t]{2}{*}{ Farm cloth and boots } & No & 15 & 41 & 1.00 & Reference & NA \\
\hline & Yes & 16 & 37 & 1.11 & $0.49,2.50$ & 0.78 \\
\hline \multirow[t]{2}{*}{ Shower bath } & No & 29 & 73 & 1.00 & Reference & NA \\
\hline & Yes & 2 & 5 & 1.16 & $0.18,7.32$ & 0.87 \\
\hline \multirow[t]{2}{*}{ Tyre dip } & No & 30 & 73 & 1.00 & Reference & NA \\
\hline & Yes & 1 & 5 & 0.52 & $0.05,4.89$ & 0.57 \\
\hline \multirow[t]{2}{*}{ Log book } & No & 31 & 72 & 1.00 & Reference & NA \\
\hline & Yes & 0 & 6 & ND & ND & ND \\
\hline \multirow[t]{2}{*}{ Use of biosecurity } & No & 3 & 6 & 1.00 & Reference & NA \\
\hline & Yes & 28 & 72 & 0.76 & $0.19,3.08$ & 0.70 \\
\hline Indiscriminate disposal of farm waste & No & 26 & 69 & 1.00 & Reference & NA \\
\hline & Yes & 5 & 9 & 1.52 & $0.46,5.00$ & 0.48 \\
\hline Self prepared feed & No & 17 & 38 & 1.00 & Reference & NA \\
\hline & Yes & 14 & 40 & 0.83 & $0.34,2.05$ & 0.70 \\
\hline Borrow farm equipment & No & 29 & 71 & 1.00 & Reference & NA \\
\hline & Yes & 2 & 7 & 0.71 & $0.13,3.77$ & 0.68 \\
\hline Untreated water source & No & 22 & 69 & 1.00 & Reference & NA \\
\hline & Yes & 9 & 9 & 3.51 & $1.13,10.92$ & 0.02 \\
\hline Pool/bird sanctuary & No & 27 & 65 & 1.00 & Reference & NA \\
\hline & Yes & 4 & 13 & 0.69 & $0.21,2.25$ & 0.54 \\
\hline Water birds visit farm premises & No & 22 & 69 & 1.00 & Reference & NA \\
\hline & Yes & 9 & 9 & 0.96 & $0.28,3.25$ & 0.95 \\
\hline Problems with rodent pests control & No & 14 & 26 & 1.00 & Reference & NA \\
\hline & Yes & 17 & 52 & 0.60 & $0.25,1.46$ & 0.26 \\
\hline Outside vaccinators operate in farm & No & 18 & 46 & 1.00 & Reference & NA \\
\hline & Yes & 13 & 32 & 1.10 & $0.48,2.52$ & 0.80 \\
\hline Bird proof buildings/pens & No & 8 & 17 & 1.00 & Reference & NA \\
\hline & Yes & 23 & 61 & 0.71 & $0.26,1.96$ & 0.51 \\
\hline Workers live outside premises & No & 7 & 40 & 1.00 & Reference & NA \\
\hline & Yes & 24 & 38 & 4.06 & $1.44,11.47$ & $<0.01$ \\
\hline Inappropriate disposal dead chickens & No & 4 & 22 & 1.00 & Reference & NA \\
\hline & Yes & 27 & 56 & 2.51 & $0.79,7.98$ & 0.11 \\
\hline
\end{tabular}

demiologic interest that took place during the months of July-October 2007, when farm managers were interviewed. Data on the following items were collected from each farm: location, primary occupation of the farm owner, education level of key decision makers (owner or manager), method of product disposal, number of layers, raising of other birds/animals, farm workers visit neighbouring farms, farmer and workers receive visitors within the farm premises, whether live poultry were purchases from the market during the epidemic in other farms, if there were infected farms within $1.0 \mathrm{~km}$, presence of footbath, presence of gate/fence, changing room, workers are provided with own cloth/boots, shower bath, tyre dip, log book, presence of preventive materials and application of procedures meant to reduce burden of diseases, disposal of farm waste, commercial/local source of feed, use of borrowed farm equipment, water source (well, lake/pool, 
stream, portable/chlorinated/borehole water), presence of pool/bird sanctuary, presence of water bird, rat problems, vaccinator of birds (resident vets, shared vaccinator/outside vets, para-veterinarians), whether the house is screened with netting to exclude wild birds, whether the workers live outside the farm premises, and the disposal method for dead bird.

\subsection{Statistical analyses}

Conditional logistic regression on the dichotomic items was used to model the odds of being an HPAI H5N1 case as a function of investigated risk factors. Initial screening of potential risk factors for HPAI H5N1 infection was performed by use of univariable conditional logistic regression (Hosmer and Lemeshow, 1989; Cytel Software Corporation, 2000). Variables associated $(P \leq 0.20)$ with the outcome of interest (HPAI H5N1 virus infection) were considered for inclusion in a multivariable logistic regression analysis. Associations between exposure variables $(P \leq 0.20)$ were examined, and when a pair of variables was associated ( $P=0.05$ by use of a $\chi^{2}$ test, two-tailed), the exposure variable judged as most biologically plausible was used as a candidate in the multivariable analysis. A forward stepwise approach was used to identify variables associated with infection by use of a 2 -sided $P$-values-to-enter and $P$-values-to-remove of 0.05 and 0.10 , respectively. Values for the final model were considered significant at $P \leq 0.05$. Fit of the model to the data was assessed by a visual examination of residual plots (standardized $\Delta-\beta$ values vs observation number and $\Delta-\beta$ vs fitted values). Case-control sets that had farms with extreme $\Delta-\beta$ values and low fitted values were excluded from the analysis to evaluate their influence on estimated ORs. In the final model, the adjusted odds ratio (OR) and 95\% confidence interval $(\mathrm{CI})$ were reported.

\section{Results}

This study included 32 case farms and 83 control farms in Nigeria. The median flock size of study poultry farms was 764 (first quartile $=351$; third quartile $=2500$ ). In the univariable analysis, 7 variables (kept other birds/animals, receive visitors on the farm, purchase live poultry, have infected neighborhood, untreated water source, outside workers, and inappropriate disposal of dead chickens) were identified and further analyzed for biological plausibility, magnitude of association, and statistical significance $(P \leq 0.20$, Table 1$)$. In the multivariable analysis, the variables 'farm receives visitors within the farm premises', 'farm purchases live poultry/products', and 'farm workers live outside the premises' were associated $(P \leq 0.05)$ with HPAI H5N1 virus infection (Table 2). Visual examination of residuals revealed that the delta-beta values for the three variables kept in the final model were not extreme (i.e., not $>1$ ), which supported overall goodness of fit. Analysis of residuals (set of case and control farms with the largest delta-beta value and lowest fitted value) indicated the existence of influential observations; however, removal of these observations did not change the finding of greater risk associated with 'farm receives visitors', purchases of

\section{Table 2}

Multivariable analysis of risk factors associated with poultry farms diagnosed with HPAI H5N1 virus infection in a case-control study on poultry farms in Nigeria.

\begin{tabular}{|c|c|c|c|c|}
\hline Variable & Category & Adjusted OR & $95 \% \mathrm{CI}$ & $P$ \\
\hline \multirow{2}{*}{$\begin{array}{l}\text { Receive visitors on } \\
\text { premises }\end{array}$} & No & 1.00 & Reference & NA \\
\hline & Yes & 8.32 & $1.87,36.97$ & $<0.01$ \\
\hline \multirow{2}{*}{$\begin{array}{l}\text { Purchase live } \\
\text { poultry }\end{array}$} & No & 1.00 & Reference & NA \\
\hline & Yes & 11.91 & $3.11,45.59$ & $<0.01$ \\
\hline \multirow{2}{*}{$\begin{array}{l}\text { Workers live } \\
\text { outside premises }\end{array}$} & No & 1.00 & Reference & NA \\
\hline & Yes & 8.98 & $1.97,40.77$ & $<0.01$ \\
\hline
\end{tabular}

live poultry/products', and 'farms with workers living outside the farms'.

\section{Discussion}

The use of epidemiologic research methods proved useful in the identification of risk factors associated with poultry farms classified as infected with HPAI H5N1 virus during the epidemic of 2006-2007 in Nigeria. While underreporting and/or over-reporting (due to confusion with other diseases) may have occurred during the epidemic, given the laboratory results conducted, such possibilities did not influence the case and control farms here investigated. Overall, the epidemiologic analysis revealed that low biosecurity standards contributed to the wide spread of HPAI H5N1 in poultry farms in Nigeria during the epidemic. Study results should help the national veterinary authority in Nigeria to justify the allocation of funds to formulate, implement, and evaluate enhanced education and communication activities on the importance of biosecurity to prevent future epidemics of HPAI in Nigeria.

Statistical significant associations were found among three risk factors (presence of visitors on farm premises, purchase of live poultry and poultry products by farmers, and farm workers living outside the farm premises). The odds of HPAI H5N1 virus infection in farms that received visitors was higher than that in farms where visitors were received outside the poultry premises $(\mathrm{OR}=8.32$; $95 \% \mathrm{CI}=1.87,36.97)$. It is noteworthy that most of the visitors that patronize farms in Nigeria are farm gate buyers who have higher chance of visiting several farms per day. In the course of conducting their trade, they may inadvertently transmit infection from farm to farm especially from a newly infected farm where clinical signs are not yet fully displayed. Similarly, farmers may offer for sale, at a lower cost, birds suspected to be infected. A previous study has indicated that transfer of poultry and their products from one part of the country to another enhances the spread of avian influenza H5N1 (Fasina et al., 2009).

Poultry farms that purchased live poultry and poultry products in the course of the outbreak had higher odds of being infected with HPAI H5N1 virus (OR $=11.91 ; 95 \%$ $\mathrm{CI}=3.11,45.59)$, compared to farms that did not. Sales of live poultry (a common practice in Nigeria and most parts of Africa) are associated with rapid dissemination of infections through slaughter, evisceration, improper disposal of 
visceral, flying feathers and contaminated equipment used by farmers (Henzler et al., 2003).

Farms with farm workers that live outside the farm had higher odds of infection, compared with farms where workers live within the premises $(\mathrm{OR}=8.98 ; 95 \% \mathrm{CI}=1.97$, 40.77). One explanation we can offer for this association is that outside workers are less likely to observe biosecurity principles and guidelines set by the farms. Such workers raise poultry in their own homes, offered services to other farms, exchange items with workers from other farm premises, and rarely change their clothes and shoes when they report for work (Adene and Oguntade, 2007).

The established risk factors are inherently behavioural: they can be modified by human decisions. Given the fact that both the control and case farms were located in the same states, the difference observed between non-infected and infected farms in terms of risk factors ruled out the role of geography as the determining factor of infection. Instead, findings suggest that, at least partially, epidemic dissemination may be diminished, if not prevented, by simple measures that essentially, involve behaviour. This study highlight the low cost but high benefit associated with educational measures meant to prevent epidemic dissemination.

\section{Acknowledgements}

We thanked the Poultry Reference Centre, Faculty of Veterinary Science, University of Pretoria, South Africa for financial support for this work. We thanked the Executive Director, National Veterinary Research Institute, Vom, Nigeria for permission to carry out the study. We acknowledge the co-operation of the poultry farmers.

\section{References}

Adene, D.F., Oguntade, A.E., 2007. The Structure and Importance of the Commercial and Village Based Poultry Industry in Nigeria, Available at: http://www.fao.org/docs/eims/upload//214281/ poultrysector_nga_en.pdf (accessed 28 January 2010).

Bavinck, V., Bouma, A., van Boven, M., Bos, M.E.H., Stassen, E., Stegeman, J.A., 2009. The role of backyard poultry in the epidemic of highly pathogenic avian influenza virus (H7N7) in the Netherlands in 2003. Prev. Vet. Med. 88, 247-254.

Bouma, A., Claassen, I., Natih, K., Klinkenberg, D., Donnelly, C.A., Koch, G., van Boven, M., 2009. Estimation of transmission parameters of H5N1 avian influenza virus in chickens. PLoS Pathog. 5 (1), e1000281, doi:10.1371/journal.ppat.1000281.

Busani, L., Valsecchi, M.G., Rossi, E., Toson, M., Ferre, N., Pozza, M.D., Marangon, S., 2009. Risk factors for highly pathogenic H7N1 avian influenza virus infection in poultry during the 1999-2000 epidemic in Italy. Vet. J. 181, 171-177.

Cattoli, L., Monne, I., Fusaro, A., Joannis, T.M., Lombin, L.H., Aly, M.M., Arafa, A.S., Sturm-Ramirez, K.M., Couacy-Hyman, E., Awuni, J.A., Batawui, K.B., Awoume, K.A., Aplogan, G.L., Sow, A., Ngangnou, A.C., Hamza, I.M.E., Gamatie, D., Dauphin, G., Domenech, J.M., Capua, I., 2009. Highly pathogenic avian influenza virus subtype H5N1 in Africa: a comprehensive phylogenetic analysis and molecular characterization of isolates. PLoS One 4 (3), e4842, doi:10.1371/journal.pone.0004842.

Couacy-Hymann, E., Danho, T., Keita, D., Bodjo, S.C., Kouakou, C., Koffi, Y.M., Beudje, F., Tripodi, A., de Benedictis, P., Cattoli, G., 2008. The First specific detection of a highly pathogenic avian influenza virus (H5N1) in ivory coast. Zoonoses Public Health 56, 10-15.

Cytel Software Corporation, 2000. EGRET for Windows, 2000. Cytel Software Corp, Cambridge, MA, USA, Available online at http://www.cytel.com/Products/Egret/default.asp (accessed on 15th January, 2010)
Ducatez, M.F., Olinger, C.M., Owoade, A.A., De Landtsheer, S., Ammerlaan, W., Niesters, H.G., Osterhaus, A.D.M.E., Fouchier, R.A.M., Muller, C.P., 2006. Avian flu: multiple introductions of H5N1 in Nigeria. Nature $442,37$.

Ducatez, M.F., Olinger, C.M., Owoade, A.A., Tarnagda, Z., Tahita, M.C., Sow, A., De Landtsheer, S., Ammerlaan, W., Ouedraogo, J.B., Osterhaus, A.D.M.E., Fouchier, R.A.M., Muller, C.P., 2007. Molecular and antigenic evolution and geographical spread of H5N1 highly pathogenic avian influenza viruses in Western Africa. J. Gen. Virol. 88, 22972306.

Fasina, F.O., Bisschop, S.P.R., Joannis, T.M., Lombin, L.H., Abolnik, C., 2009. Molecular characterization and epidemiology of the highly pathogenic avian influenza H5N1 in Nigeria. Epidemiol. Infect. 137, 456-463.

Guan, Y., Peiris, J.S.M., Lipatov, A.S., Ellis, T.M., Dyrting, K.C., Zhang, L.J., Webster, R.G., Shortridge, K.F., 2002. Emergence of multiple genotypes of H5N1 avian influenza viruses in Hong Kong SAR. PNAS (USA) 99(13), 8950-8955.

Henzler, D.J., Kradel, D.C., Davison, S., Ziegler, A.F., Singletary, D., DeBok, P., Castro, A.E., Lu, H., Eckroade, R., Swayne, D., Lagoda, W., Schmucker B., Nesselrodt, A., 2003. Epidemiology, production losses, and control measures associated with an outbreak of avian influenza subtype H7N2 in Pennsylvania (1996-1998). Avian Dis. 47 (supplement 3), $1022-1036$.

Hosmer, D.W., Lemeshow, S., 1989. Logistic regression for matched case-control studies. In: Hosmer, D.W., Lemeshow, S. (Eds.), Applied Logistic Regression. Wiley, New York, pp. 187-215.

Joannis, T.M., Meseko, C.A., Oladokun, A.T., Ularamu, H.G., Egbuji, A.N., Solomon, P., Nyam, D.C., Gado, D.A., Luka, P., Ogedengbe, M.E., Yakubu, M.B., Tyem, A.D., Akinyede, O., Shittu, A.I., Sulaiman, L.K., Owolodun, O.A., Olawuyi, A.K., Obishakin, E.T., Fasina, F.O. 2008. Serologic and virologic surveillance of avian influenza in Nigeria, 2006-2007. EuroSurveillance 13 (42), pii=19007 Available online: http://www.eurosurveillance.org/ViewArticle.aspx? (ArticleId $=19007$ )

Li, K.S., Guan, Y., Wang, J., Smith, G.J.D., Xu, K.M., Duan, L., Rahardjo, A.P., Puthavathana, P., Buranathai, C., Nguyen, T.D., Estoepangestie, A.T.S., Chaisingh, A., Auewarakul, P., Long, H.T., Hahn, N.T.H., Webby, R.J., Poon, L.L.M., Chen, H., Shortridge, K.F., Yuen, K.Y., Webster, R.G., Peiris, J.S.M., 2004. Genesis of a highly pathogenic and potentially pandemic H5N1 influenza virus in Eastern Asia. Nature 430 (6996), 209-213.

Nishiguchi, A., Kobayashi, S., Yamamoto, T., Ouchi, Y., Sugizaki, T., Tsutsui, T., 2007. Risk factors for the introduction of avian influenza virus into commercial layer chicken farms during the outbreaks caused by a lowpathogenic H5N2 virus in Japan in 2005. Zoonoses Public Health 54 337-343.

Njouom, R., Aubin, J.-T., Bella, A.L., Demsa, B.M., Rouquet, P., Gake, B., Ngangnou, A., Foupouapouognigni, Y., Van Der Werf, S., Rocourt, J., Rousset, D., 2008. Highly pathogenic avian influenza virus subtype H5N1 in ducks in the Northern part of Cameroon. Vet. Microbiol. 130, 380-384.

Tiensin, T., Chaitaweesub, P., Songserm, T., Chaisingh, A., Hoonsuwan, W., Buranathai, C., Parakamawongsa, T., Premashthira, S., Amonsin, A., Gilbert, M., Nielen, M., Stegeman, A., 2005. Highly pathogenic avian influenza H5N1, Thailand, 2004. Emerg. Infect. Dis. 11, 16641672

Thomas, M.E., Bouma, A., Ekker, H.M., Fonken, A.J., Stegeman, J.A., Nielen, M., 2005. Risk factors for the introduction of high pathogenicity avian influenza virus into poultry farms during the epidemic in the Netherlands in 2003. Prev. Vet. Med. 69, 1-11.

Thompson, P.N., Sinclair, M., Ganzevoort, B., 2008. Risk factors for seropositivity to $\mathrm{H} 5$ avian influenza virus in ostrich farms in the Western Cape Province. South Africa. Prev. Vet. Med. 86, 139152.

Xu, X., Subbarao, K., Cox, N., Gou, Y., 1999. Genetic characterization of the pathogenic influenza A/Goose/Guangdong/1/96 (H5N1) virus: similarity of its haemagglutinin gene to those of H5N1 viruses from the 1997 outbreaks in Hong Kong. Virology 261, 15-19.

World Health Organisation (WHO) (2010), 2010. Cumulative Number of Confirmed Human Cases of Avian Influenza A/(H5N1) Reported to the WHO. 24th September, 2009, Available at: http://www.who.int/csr/disease/avian_influenza/country/cases table_2009_09_24/en/index.html (accessed on 5th January).

World Organisation for Animal Health (OIE) (2010), 2010. OIE Daily Update on Avian Influenza Situation in Birds, Available at: www.oie.int/downld/Avian\%20INFLUENZA/A_AI_Asia.htm (accessed on 5 th January). 